\title{
EFFECT OF VERMICOMPOST EXTRACT AND VERMICOMPOST- DERIVED HUMIC ACIDS ON SEED GERMINATION AND SEEDLING GROWTH OF HEMP
}

\author{
Gederts levinsh $^{1, \#}$, Māra Vikmane ${ }^{1}$, Agnese Ķirse ${ }^{1}$, and Andis Karlsons ${ }^{2}$ \\ 1 Faculty of Biology, University of Latvia, 1 Jelgavas Str., Riga, LV-1004, LATVIA \\ 2 Institute of Biology, University of Latvia, 3 Miera Str., Salaspils, LV-2169, LATVIA \\ \# Corresponding author, gederts.ievins@lu.lv
}

Communicated by Ina Alsina

\begin{abstract}
Hemp (Cannabis sativa L.) cultivars grown for industrial use have recently emerged as a sustainable alternative source of industrial fibre and bioenergy, and is a highly valuable food and animal feed resource. The aim of the present study was to evaluate the effect of vermicompost extract, vermicompost mineral nutrient composition, and vermicompost-derived humic and fulvic acids on seed germination and growth of hemp seedlings. In general, separate application of all vermicompost components stimulated seed germination and hypocotyl and radicle growth, as well as increased chlorophyll concentration in cotyledons. Effective concentration range and the degree of stimulation varied significantly between the treatments. For practical purposes, application of vermicompost and vermicompost-derived extracts for stimulation of hemp growth could be useful at concentrations $5 \%, 0.05 \mathrm{mg} \cdot \mathrm{mL}^{-1}$ and $1 \%$, for vermicompost extract, humic acids and fulvic acids, respectively.
\end{abstract}

Key words: Cannabis sativa, chlorophyll, growth, humic acids, vermicompost.

\section{INTRODUCTION}

The term "hemp" refers to Cannabis sativa L. cultivars grown for industrial use. Hemp has been traditionally cultivated for both fibre and seed oil for thousands of years (Xiaozhai and Clarke, 1995). Due to different reasons, hemp cultivation and production drastically decreased after the Second World War, especially, in North America (Callaway, 2004). Recent renewed interest in hemp has been due to the need for sustainable production of multipurpose natural resources as an alternative source for industrial fibre (Ranalli and Venturi, 2004). The use of hemp stalks includes textiles, paper production, fuel, biodegradable plastics, construction materials, etc. Hemp seeds are rich in oils with a high content of essential fatty acids, with $56 \%$ linoleic acid and 22\% $\alpha$-linolenic acid (Callaway, 2004), making them suitable as a resource both for human food and animal feed. In addition, hemp is emerging as an efficient bioenergy crop species (Finnan and Styles, 2013; Sausserde and Adamovics, 2013).

Hemp is extremely suitable for organic agriculture production because of strong natural resistance to most pathogens and herbivores (van der Werf, 1994). Also, with proper tight spacing, weed growth is completely suppressed in hemp fields, and consequently, no herbicide treatment is necessary. However, contrary to a popular belief, hemp cultivation requires sufficiently high soil mineral nutrient levels (Berger, 1969; Malceva et al., 2011; Adamovics et al., 2016).

Sustainable agricultural production, especially in organic agriculture, requires new means of fertilisation and plant protection. The use of variety of fertilizers and other products derived from organic waste is extremely promising in light of renewable resource utilisation (Šimon and Czakó, 2014). Processing of biological waste by a corporate action of earthworms and microorganisms is involved in the production of the organic fertiliser vermicompost, which is rich in humic substances and mineral nutrients (Lazcano et al., 2008). This fertilizer improves soil fertility related characteristics (Ferreras et al., 2006) and has a multifaceted biological action on plants. Plant growth promotion (Ievinsh, 2011; Grantina-Ievina et al., 2013), and induction of resistance against pathogens (Zaller, 2006; Ersahin et al., 2009) and herbivores (Edwards et al., 2011, Cardoza and Buhler, 2012) are among the well-known effects of vermicompost application. In particular, plant growth-promoting activity of vermicomposts has been usually attributed to the high content of humic compounds (Muscolo et al., 1999). 
In addition, because of the relatively high mineral content in vermicomposts, part of the growth-enhancing activity of vermicompost and vermicompost extracts might be due to the positive effect of additional mineral nutrients on plant growth (Karlsons et al., 2016). However, in the majority of studies, the relative effect of these different factors on vermicompost-treated plants has not been discriminated. Therefore, the aim of the present study was to evaluate relative efficiency of vermicompost components, namely, mineral nutrients, fulvic acids and humic acids on plant growth-affecting activity using a seed germination/seedling growth test with industrial hemp seeds.

\section{MATERIALS AND METHODS}

Hemp cultivar 'Pūriņi' of Latvian origin obtained from local growers was used in the present study.

Vermicompost extract was prepared using vermicompost made from composted cow manure and composted grass as described previously (Grantina-Ievina et al., 2013). A sample of vermicompost $(1 \mathrm{~L})$ was mixed with $1 \mathrm{~L}$ water and incubated at room temperature for $4 \mathrm{~h}$, stirring occasionally. The slurry was filtered through a paper filter (grade 1) and used as a $50 \%$ vermicompost extract.

Mineral nutrient concentration in vermicompost extract was determined using colorimetry (N, P, Mo, B), atomic absorption spectrophotometry ( $\mathrm{Ca}, \mathrm{Mg}, \mathrm{Fe}, \mathrm{Cu}, \mathrm{Zn}, \mathrm{Mn}$ ) and flame photometry $(\mathrm{K})$ according to the previously published protocol (Karlsons et al., 2008). Mineral nutrient concentration of vermicompost is shown in Table 1. To determine the effect of vermicompost extract mineral nutrients on hemp seed germination and growth, a mineral solution with identical macronutrient concentrations was prepared using 233 $\mathrm{mg} \cdot \mathrm{L}^{-1} \mathrm{CaCO}_{3}, 731 \mathrm{mg} \cdot \mathrm{L}^{-1} \mathrm{MgSO}_{4} 7 \mathrm{H}_{2} \mathrm{O}, 349 \mathrm{mg} \cdot \mathrm{L}^{-1}$ $\mathrm{MgCl}_{2} 6 \mathrm{H}_{2} \mathrm{O}, 186 \mathrm{mg} \cdot \mathrm{L}^{-1} \mathrm{~K}_{2} \mathrm{HPO}_{4} 3 \mathrm{H}_{2} \mathrm{O}, 979 \mathrm{mg} \cdot \mathrm{L}^{-1}$ $\mathrm{KNO}_{3}$, and $2675 \mathrm{mg} \cdot \mathrm{L}^{-1} \mathrm{~K}_{2} \mathrm{CO}_{3}$.

Table 1

MINERAL CONTENT (MG.L ${ }^{-1}$ ) AND ELECTRICAL CONDUCTIVITY (EC; MS.CM ${ }^{-1}$ ) OF VERMICOMPOST EXTRACT USED IN THE PRESENT STUDY

\begin{tabular}{l|c}
\hline \multicolumn{1}{c|}{ Element } & Vermicompost extract (50\%) \\
\hline $\mathrm{N}$ & 137 \\
$\mathrm{P}$ & 26 \\
$\mathrm{~K}$ & 1970 \\
$\mathrm{Ca}$ & 93 \\
$\mathrm{Mg}$ & 115 \\
$\mathrm{~S}$ & 95 \\
$\mathrm{Fe}$ & 0.18 \\
$\mathrm{Mn}$ & 0.02 \\
$\mathrm{Zn}$ & 0.08 \\
$\mathrm{Cu}$ & 0.07 \\
$\mathrm{~B}$ & 0.16 \\
$\mathrm{Na}$ & 178 \\
$\mathrm{Cl}$ & 450 \\
$\mathrm{EC}$ & 7.72
\end{tabular}

Humic substances were isolated from the same vermicompost material following the principles of Muscolo et al. (1999). A sample of vermicompost (500 g) was suspended in $850 \mathrm{~mL} 0.1 \mathrm{M} \mathrm{KOH}$ and extracted for $6 \mathrm{~h}$ at room temperature. Extract was filtered through filter paper and $6 \mathrm{M}$ $\mathrm{HCl}$ was gradually added to reach $\mathrm{pH}$ 2.0. The resulting solution was kept at $5{ }^{\circ} \mathrm{C}$ for $24 \mathrm{~h}$, leading to precipitation of humic acid. Precipitated humic acid was separated from the solution by filtration through paper filter. Dried residue was ground to powder using a mortar and pestle. Humic acid was washed with $500 \mathrm{~mL}$ water, filtered and dried. The procedure was repeated twice with $200 \mathrm{~mL}$ of water. Filtered solution obtained after recovery of precipitated humic acid was used as fulvic acid-enriched product.

Vermicompost extract concentrations used for treatment were $1,2,5,10,20$, and 50\%. For mineral nutrient treatments, a source solution was prepared, as described above, containing the same amount of macronutrients as in $50 \%$ vermicompost extract. The source solution was proportionally diluted to obtain the same concentrations of minerals as for respectively diluted vermicompost extract. Humic acid was dissolved in $0.1 \mathrm{M} \mathrm{KOH}$ and used in concentrations $0.05,0.1,0.5$, and $1 \mathrm{mg} \cdot \mathrm{mL}^{-1}$. Fulvic acid-enriched solution was used undiluted $(100 \%)$ or diluted to $1,5,10,25$, and $50 \%$. Solutions of humic and fulvic acids were neutralised with $1 \mathrm{M} \mathrm{HCl}$ to $\mathrm{pH}$ 7.0. As a control, deionised water (in the case of vermicompost extract and mineral treatments) or neutralised $0.1 \mathrm{M} \mathrm{KOH}$ (in the case of humic and fulvic acids treatment) were used. For the sake of clarity, in graphs all treatments were equalised in respect to the relative amount of vermicompost used to prepare the respective amount of the product (Table 2).

Plant growth-affecting activity was measured by seed germination and seedling growth tests (Ievinsh, 2011; Grantina-Ievina et al., 2013). Hemp seeds were imbibed in water or respective test solution for $4 \mathrm{~h}$, and then placed on

$$
\text { Table } 2
$$

CONCENTRATION OF DIFFERENT PREPARATIONS USED FOR TREATMENT IN RESPECT TO EQUIVALENT DOSE OF VERMICOMPOST

\begin{tabular}{l|c|c|c|c}
\hline $\begin{array}{c}\text { Equivalent } \\
\text { dose of } \\
\text { vermicompost } \\
(\mathrm{mL})\end{array}$ & $\begin{array}{c}\text { Vermicompost } \\
\text { extract }(\%)\end{array}$ & $\begin{array}{c}\text { Mineral } \\
\text { nutrient } \\
\text { solution } \\
(\%)\end{array}$ & $\begin{array}{c}\text { Humic acid } \\
\left(\mathrm{mg}^{-1} \mathrm{~mL}^{-1}\right)\end{array}$ & $\begin{array}{c}\text { Fulvic acid } \\
(\%)\end{array}$ \\
\hline 0.25 & - & - & - & 1 \\
1.00 & 1 & 1 & - & - \\
1.25 & - & - & 0.05 & 5 \\
2.00 & 2 & 2 & - & - \\
2.50 & - & - & 0.1 & 10 \\
5.00 & 5 & 5 & - & - \\
6.25 & - & - & - & 25 \\
10.00 & 10 & 10 & - & - \\
12.50 & - & - & 0.5 & 50 \\
20.00 & 20 & 20 & - & - \\
25.00 & - & - & 1.0 & 100 \\
50.00 & 50 & 50 & - & -
\end{tabular}


Petri dishes (30 seeds per dish) on filter paper soaked in appropriate solution in five replicates. After incubation at room temperature in darkness for six days, germinated seeds were counted and length of both hypocotyl and radicle was measured. Then Petri dishes were placed in a growth cabinet with $120 \mu \mathrm{mol} \cdot \mathrm{m}^{-2} \cdot \mathrm{s}^{-1}$ photosynthetic photon flux of photosynthetically active radiation for $12 \mathrm{~h}$ at 24 ${ }^{\circ} \mathrm{C}$ and chlorophyll concentration in cotyledons was measured using a Minolta SPAD chlorophyll meter, 30 readings per treatment. Finally, hypocotyl and radicle were separated and fresh mass was measured.

All results were expressed relative to the control as means (\%) \pm standard error. Significant differences of parameters between treatments were determined by the Tukey-Kramer test at the level of $\alpha=0.05$.

\section{RESULTS}

Treatment of hemp seeds with vermicompost water extract resulted in stimulation of germination, and the effect was statistically significant at 1 to $5 \%$ extract concentration (Fig. $1 ; 1$ to $5 \mathrm{~mL}$ equivalent dose). Mineral solution was significantly effective only at $2 \%$ ( $2 \mathrm{~mL}$ equivalent dose), while the treatment with 10 to $50 \%$ solution $(10$ to $50 \mathrm{~mL}$ equivalent dose) resulted in significant inhibition of seed germination. Both humic and fulvic acid showed tendency for increased germination, but the effect was statistically significant only at $0.1 \mathrm{mg} \cdot \mathrm{mL}^{-1}$ humic acid $(2.5 \mathrm{~mL}$ equivalent dose) and $1 \%$ fulvic acid $(0.25 \mathrm{~mL}$ equivalent dose).

Seed treatment with vermicompost extract significantly stimulated hypocotyl growth in a concentration range from 1 to $20 \%$ (Fig. $2 \mathrm{~A} ; 1$ to $20 \mathrm{~mL}$ equivalent dose). The highest effect (45\% stimulation) was seen in the case of the $5 \%$ treatment ( $5 \mathrm{~mL}$ equivalent dose). However, application of $50 \%$ extract $(50 \mathrm{~mL}$ equivalent dose) resulted in significant growth inhibition of hemp hypocotyls. Treatment with mineral solution was significantly effective in hypocotyl growth

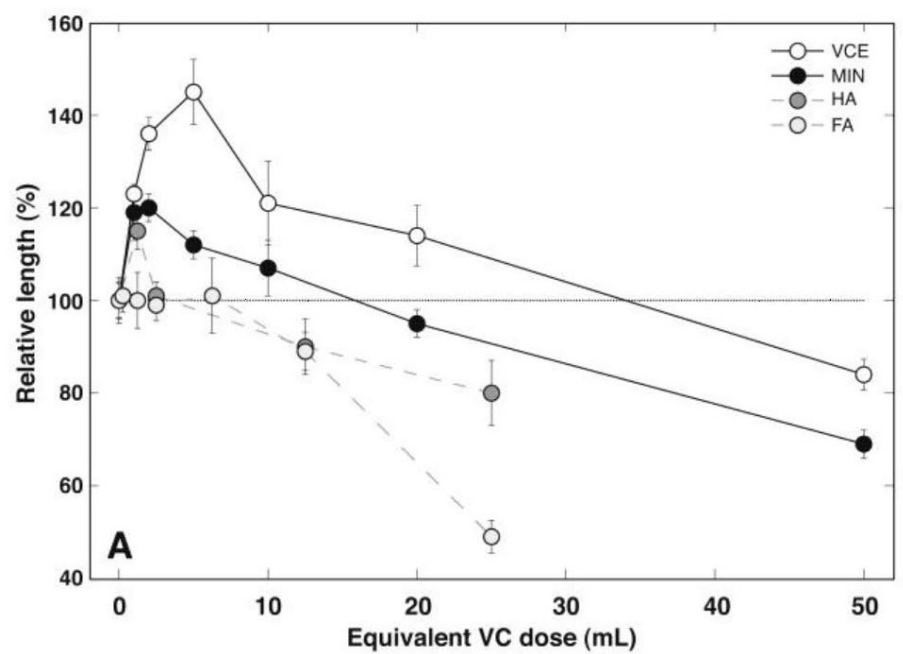

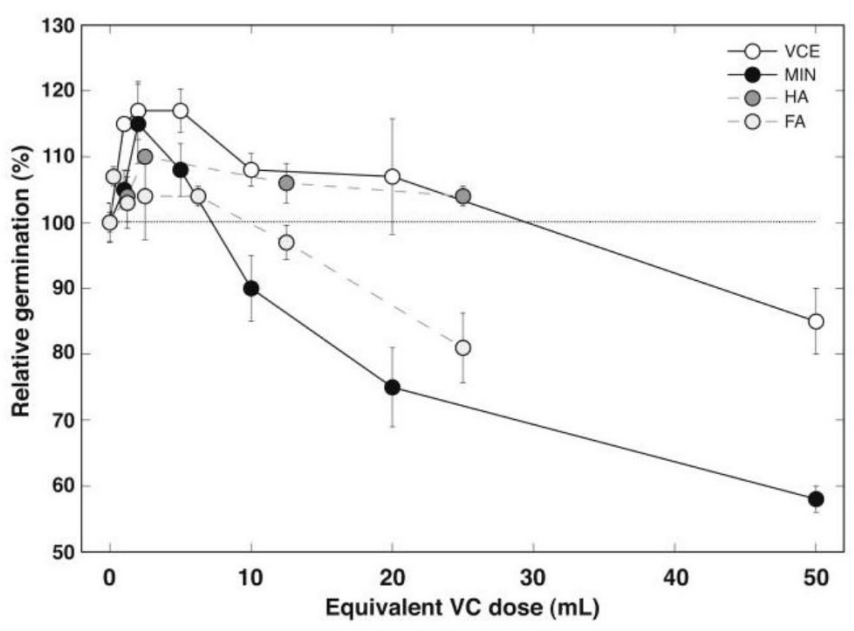

Fig. 1. Effect of vermicompost extract (VCE), mineral nutrients (MIN), humic acid (HA) and fulvic acid (FA) on relative seed germination of hemp. The treatments were equalised in respect to the relative amount of vermicompost used to prepare the product. As a control, deionised water (VCE, MIN) or $0.1 \mathrm{M} \mathrm{KOH} \mathrm{(HA,} \mathrm{FA)} \mathrm{was} \mathrm{used.} \mathrm{Data} \mathrm{are} \mathrm{means} \pm \mathrm{SE}$ from five replications. The control levels for seed germination were $82.0 \pm$ $1.7 \%$ (water) and $90.7 \pm 1.3 \%(\mathrm{KOH})$.

stimulation in a range from 1 to $10 \%$ ( 1 to $10 \mathrm{~mL}$ equivalent dose). Application of humic acid significantly enhanced hypocotyl growth at the $0.05 \mathrm{mg} \cdot \mathrm{L}^{-1}$ treatment $(1.25 \mathrm{~mL}$ equivalent dose), while for fulvic acid this effect was significant for 1 to $5 \%$ treatments $(0.25$ to $1.25 \mathrm{~mL}$ equivalent dose). Relatively high concentration of minerals (20 to $50 \%, 20$ to $50 \mathrm{~mL}$ equivalent dose) and humic substances [0.5 to $1.0 \mathrm{mg} \cdot \mathrm{mL}^{-1}$ for humic acid $(12.5$ to $25.0 \mathrm{~mL}$ equivalent dose) and $100 \%$ for fulvic acid $(25 \mathrm{~mL}$ equivalent dose)] resulted in significant growth inhibition.

A similar effect was evident for radicle growth, where the significantly effective concentration range of vermicompost extract was 1 to $10 \%$ ( 1 to $10 \mathrm{~mL}$ equivalent dose), with significant inhibition at $50 \%(50 \mathrm{~mL}$ equivalent dose; Fig. 2B). The maximum stimulative effect of vermicompost ex-

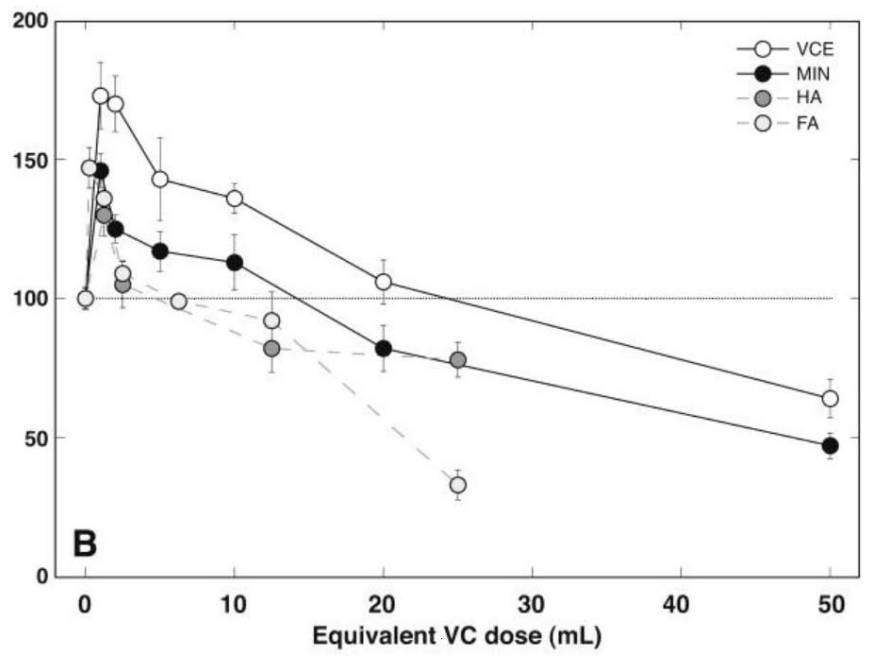

Fig. 2. Effect of vermicompost extract (VCE), mineral nutrients (MIN), humic acid (HA) and fulvic acid (FA) on growth of hypocotyl (A) and radicle (B) of hemp seedlings. The treatments were equalised in respect to the relative amount of vermicompost used to prepare the product. As a control, deionised water (VCE, MIN) or 0.1 M KOH (HA, FA) was used. Data are means \pm SE from five replications. The control levels for hypocotyl length were $3.42 \pm 0.09 \mathrm{~cm}$ (water) and $3.57 \pm 0.08 \mathrm{~cm}(\mathrm{KOH})$. The control levels for radicle length were $3.39 \pm 0.06 \mathrm{~cm}($ water $)$ and $3.49 \pm 0.43 \mathrm{~cm}(\mathrm{KOH})$. 

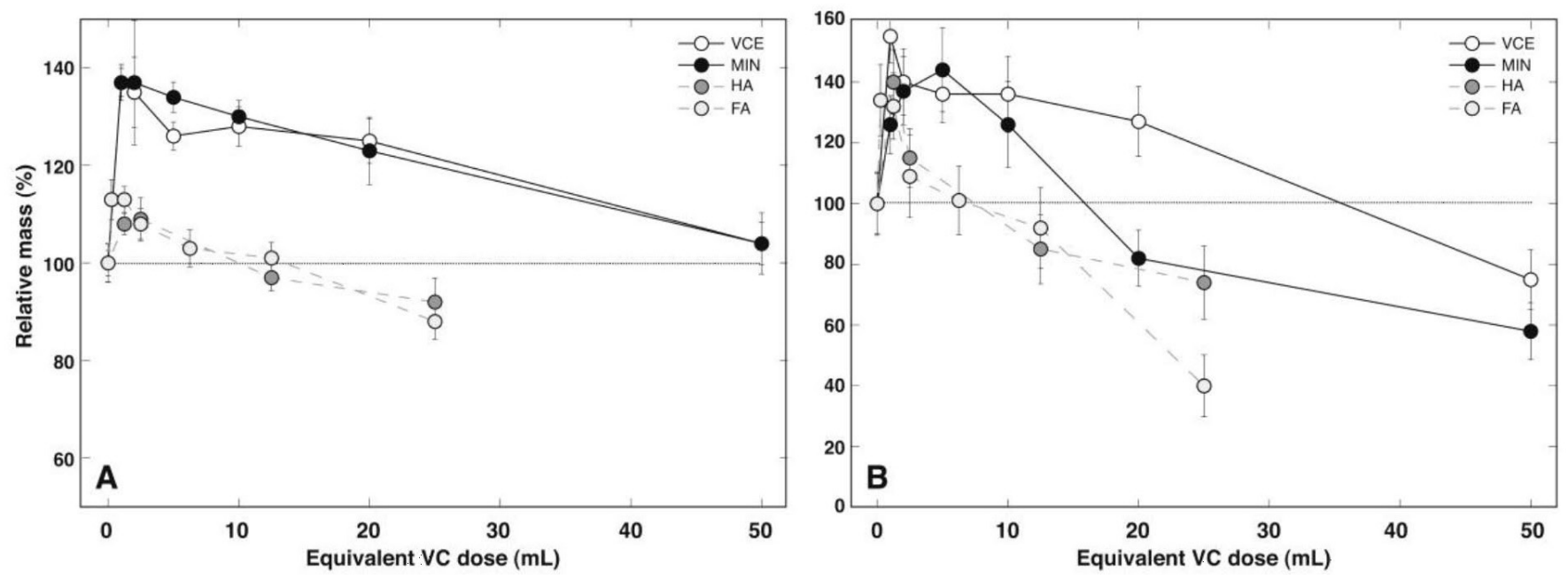

Fig. 3. Effect of vermicompost extract (VCE), mineral nutrients (MIN), humic acid (HA) and fulvic acid (FA) on fresh mass of hypocotyl (A) and radicle (B) of hemp seedlings. The treatments were equalised in respect to the relative amount of vermicompost used to prepare the product. As a control, deionised water (VCE, MIN) or 0.1 M KOH (HA, FA) was used. Data are means \pm SE from five replications. The control levels for hypocotyl mass were $43.9 \pm 1.0$ mg (water) and $47.2 \pm 1.5 \mathrm{mg}(\mathrm{KOH})$. The control levels for radicle mass were $11.4 \pm 0.4 \mathrm{mg}($ water $)$ and $10.6 \pm 0.5 \mathrm{mg}(\mathrm{KOH})$.

tract on radicle growth was a $73 \%$ increase in the $1 \%$ treatment ( $1 \mathrm{~mL}$ equivalent dose). The concentration range of significant radicle growth stimulation for mineral solution was 1 to $2 \%$ (1 to $2 \mathrm{~mL}$ equivalent dose), but for humic and fulvic acid $0.05 \mathrm{mg} \cdot \mathrm{mL}^{-1}(1.25 \mathrm{~mL}$ equivalent dose $)$ and 1 to $5 \%$ ( 0.25 to $1.25 \mathrm{~mL}$ equivalent dose), respectively.

Fresh mass of hemp hypocotyls significantly increased both due to vermicompost extract and mineral solution treatment in the range from 1 to $20 \%$ ( 1 to $20 \mathrm{~mL}$ equivalent dose; Fig. 3A). Significant hypocotyl mass increase was evident for 0.05 to $0.1 \mathrm{mg} \cdot \mathrm{mL}^{-1}$ humic acid $(1.25$ to $2.50 \mathrm{~mL}$ equivalent dose) and 1 to $10 \%$ fulvic acid $(0.25$ to $2.50 \mathrm{~mL}$ equivalent dose) treatment. Radicle mass of hemp seedlings significantly increased in vermicompost extract (1 to 20\%, 1 to $20 \mathrm{~mL}$ equivalent dose) and mineral solution (1 to $10 \%, 1$ to $10 \mathrm{~mL}$ equivalent dose) treatments (Fig. 3B). Humic acid had significant stimulative effect on radicle mass only at $0.05 \mathrm{mg} \cdot \mathrm{mL}^{-1}(1.25 \mathrm{~mL}$ equivalent dose), while fulvic acid was effective at 1 to $5 \%$ ( 0.25 to $1.25 \mathrm{~mL}$ equivalent dose). High concentration of humic substances resulted in decrease of hemp seedling mass.

Vermicompost extract treatment of hemp seeds resulted in significant increase in cotyledon chlorophyll concentration over the whole range of concentration used (Fig. 4). For mineral nutrient solution, this effect was seen only in the $0 \%$ treatment $(10 \mathrm{~mL}$ equivalent dose). Similar to vermicompost extract, humic acid was effective in increasing of chlorophyll content over the whole concentration range. However, fulvic acid was significantly effective only from concentrations 10 to $25 \%$ (2.5 to $12.5 \mathrm{~mL}$ equivalent dose).

\section{DISCUSSION}

In the present study it was attempted to experimentally separate the effect of different components of vermicompost extract on germination and seedling growth of hemp plants.

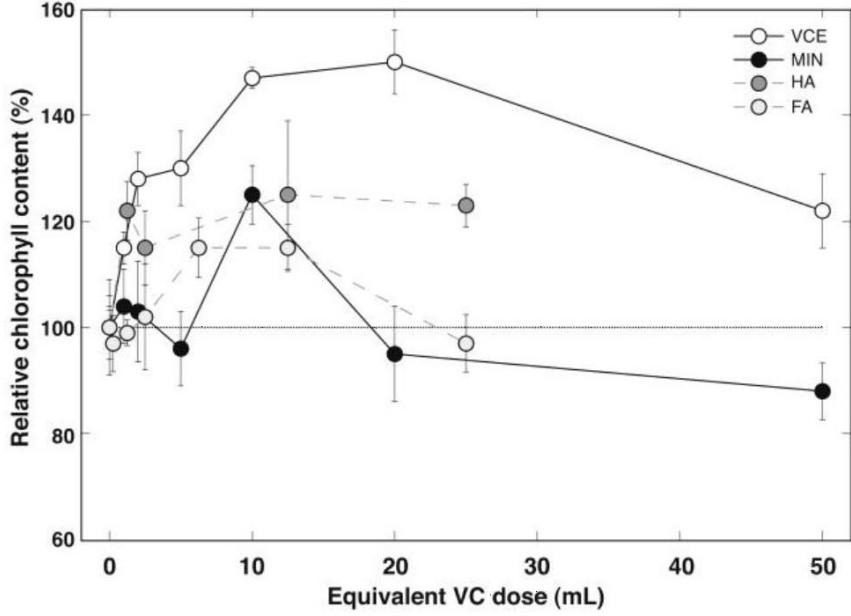

Fig. 4. Effect of vermicompost extract (VCE), mineral nutrients (MIN), humic acid (HA) and fulvic acid (FA) on relative chlorophyll concentration in cotyledons of hemp seedlings. The treatments were equalised in respect to the relative amount of vermicompost used to prepare the product. As a control, deionised water (VCE, MIN) or $0.1 \mathrm{M} \mathrm{KOH} \mathrm{(HA,} \mathrm{FA)} \mathrm{was} \mathrm{used.}$ Data are means \pm SE from five replications. The control levels for chlorophyll content were $27.4 \pm 1.3$ SPAD units (water) and $24.3 \pm 2.2$ SPAD units $(\mathrm{KOH})$.

As humic acids are insoluble in water, they are not normally available for plants, in contrast to water-soluble fulvic acids. Therefore, when native vermicompost or vermicompost extract is used for plant treatment, the growth promoting effect can be due to the fulvic acid fraction of humic substances as well as other chemical components, including mineral substances. The results from individual treatments (Figs. 1 to 3 ) were used to calculate growth-affecting activity of vermicompost extract, excluding effect of mineral nutrients, and the remaining activity was compared with that of fulvic acid (Fig. 5). It is evident that besides mineral substances and fulvic acid, other components are responsible for different aspects of biological activity found in vermicompost and its extracts. However, the experimental procedure used (preparation of vermicompost extract, isolation of 


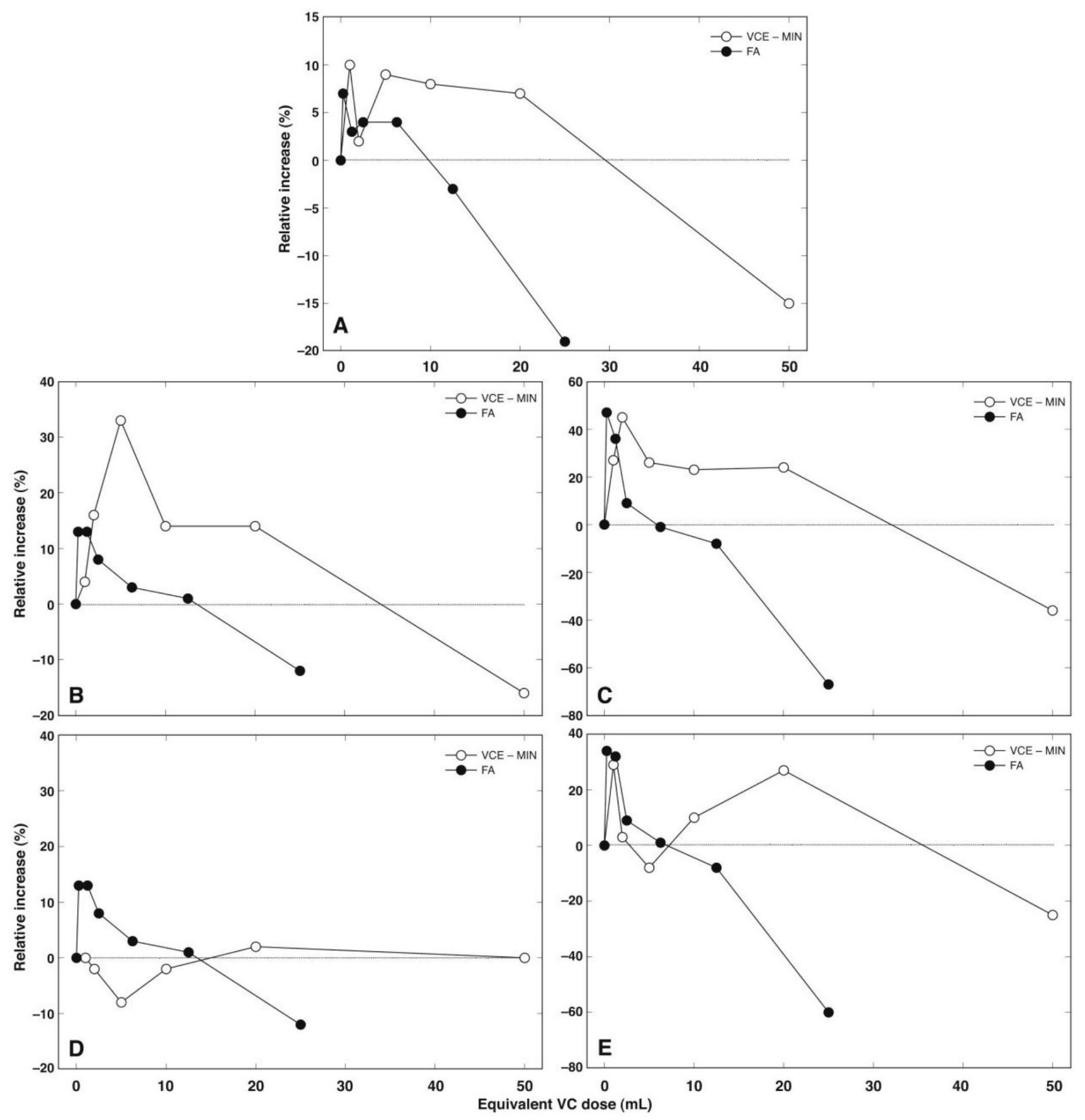

Fig. 5. Comparative relative effect of vermicompost extract minus vermicompost mineral nutrient concentration (VCE - MIN) vs. fulvic acid (FA) treatment on hypocotyl length (A), radicle length (B), hypocotyl fresh mass (C), radicle fresh mass (E), and relative seed germination of hemp. Data are derived from Figs. 1 to 3.

humic acid and fulvic acid-enriched fraction from vermicompost) did not allow for quantitative separation of different chemical substances, as chemical fractionation was not used. Therefore, biological activity found in any of the respective treatments can be used only as an approximate indication of contribution of the chemical components.

Mineral nutrients in plant-available forms are one of the beneficial characteristics of vermicompost (Grantina-Ievina et al., 2015). The actual concentrations of various inorganic nutrients in particular vermicompost preparations depend on the initial mineral composition of the feedstock used as well as on intensity of mineralisation activity of respective microorganisms during precomposting and vermicomposting stages (Domínguez, 2004; Pattnaik and Reddy, 2010). As different crop species have various degrees of sensitivity to added minerals at the germination stage, indicating differences in timing of onset of autotrophic growth (McWilliam et al., 1970), it is difficult to predict the actual impact of particular vermicompost mineral nutrients. 
Other potential beneficial mechanisms of vermicompost on plants include hormone-like effect on plant growth (Tomati et al., 1988) as well as stimulation of plant mineral nutrition (Pant et al., 2009). In a study with winter rye plants, where vermicompost was applied as a soil amendment at optimal mineral nutrient level, a significant growth promoting effect was evident even at $10 \%$ substitution, while positive effect of treatment on mineral nutrient accumulation was seen only at higher doses, pointing to activity of vermicompostderived biologically active substances (Karlsons et al., 2016). This contradicts several studies showing beneficial effect of vermicompost and, in particular, humic substances on plant mineral nutrition (David et al., 1994; Chen et al., 2004). However, in a study with different vegetable species it was shown that in conditions of typical vegetable production application of humic substances did not significantly improve crop mineral nutrition and productivity (Hartz and Bottoms, 2010).

Increase in leaf chlorophyll content due to vermicompost extract treatment can be used as an indication of improved physiological state of plants (Ievinsh, 2011). This effect was observed also in humic and fulvic acid treatments in the present study (Fig. 4) as well as in other experiments (Yang et al., 2004; Xu et al., 2012) suggesting activation of photosynthesis-related processes by vermicompost components.

Root growth of gerbera significantly increased in plants treated with nutrient solution containing $1 \mathrm{~g} \cdot \mathrm{L}^{-1}$ of humic acid isolated from leonardite, with no effect on shoot growth (Nikbakht et al., 2008). In comparison, the effective concentration of humic acid from vermicompost resulting in significant growth enhancement of both hypocotyl and radicle of hemp seedlings in the present study was 20-fold lower (50 mg. $\mathrm{L}^{-1}$; Figs. 1 and 2$)$. A similar dose of humic acid extracted from organic waste was reported to be optimum for promotion of both shoot and root growth of maize plants (Eyheraguibel et al., 2008). However, massive changes of gene expression in Arabidopsis thaliana plants have been induced by treatment with vermicompost-derived humic acid at the concentration of $1 \mathrm{mg} \cdot \mathrm{L}^{-1}$ (Trevisan et al., 2011).

It seems that it is important to discriminate between effects of preparations containing humic substances made from "dead" organic sources (coal, leonardite, peat) vs. humic substances isolated from organic materials containing living microorganisms (biological waste, compost, vermicompost), as both chemical properties and biological activity are variable (Campitelli and Ceppi, 2008; Pedra et al., 2008). Humic substance-containing preparations from biological waste potentially could have higher biological activity (Xu et al., 2012).

In conclusion, the observed positive effect of vermicompost extract on hemp seed germination, growth and physiological state can be attributed to complex action of different vermicompost components, including mineral nutrients, fulvic acids and other biologically-active substances. For prac- tical purposes, application of vermicompost and vermicompost-derived extracts for stimulation of hemp growth could be useful at concentrations $5 \%, 0.05 \mathrm{mg} \cdot \mathrm{mL}^{-1}$ and $1 \%$, for vermicompost extract, humic acids and fulvic acids, respectively. More intensive growth of hemp seedlings can be advantageous because of faster weed suppression due to earlier canopy closure. The treatment could have positive effect also on yield, as a one-year field study using different doses of vermicompost as a soil amendment indicated improved biomass accumulation and seed production of industrial hemp plants (M. Vikmane, A. Kirse, G. Ievinsh, unpublished data).

\section{REFERENCES}

Adamovics, A., Ivanovs, S., Stramkale, V. (2016). Investigations about the impact of norms of the fertilisers and cultivars upon the crop capacity biomass of industrial hemp. Agron. Res., 14 (3), 641-649.

Berger, J. (1969). The World's Major Fibre Crops: their Cultivation and Manuring. Centre d'Etude de l'Azote, Zurich. 294 pp.

Callaway, J. J. (2004). Hempseed as a nutritional resource: An overview. Euphytica, 140 (1), 65-72.

Campitelli, P., Ceppi, S. (2008). Effects of composting technologies on the chemical and physicochemical properties of humic acids. Geoderma, 144 (1-2), 325-333.

Cardoza, Y. J., Buhler, W. G. (2012). Soil organic amendment impacts on corn resistance to Helicoverpa zea: Constitutive or induced? Pedobiologia, 55 (6), 343-347.

Chen, Y., Clapp, C. E., Magen, H. (2004). Mechanisms of plant growth stimulation by humic substances: The role of organo-iron complexes. Soil Sci. Plant Nutr., 50 (7), 1089-1095.

David, P. P., Nelson, P. V., Sanders, D. C. (1994). A humic acid improves growth of tomato seedling in solution culture. J. Plant Nutr., 17 (1), 173-184.

Domínguez, J. (2004). State-of-the-art and new perspectives on vermicomposting research. In: Edwards, C. A. (Ed.). Earthworm Ecology, $2^{\text {nd }}$ ed. CRC Press, Boca Raton, pp. 401-424.

Edwards, C. A., Arancon, N. Q., Vasko-Bennett, M., Askar, A., Keeney, G. (2011). Effect of aqueous extracts from vermicomposts on attacks by cucumber beetles (Acalymna vittatum) (Fabr.) on cucumbers and tobacco hornworm (Manduca sexta) (L.) on tomatoes. Pedobiologia, 53 (2), $141-148$.

Eyheraguibel, B., Silvestre, J., Morard, P. (2008). Effects of humic substances derived from organic waste enhancement on the growth and mineral nutrition of maize. Bioresour. Technol., 99 (10), 4206-4212.

Ersahin, Y. S., Haktanir, K., Yanar, Y. (2009). Vermicompost suppresses Rhizoctonia solani Kühn in cucumber seedlings. J. Plant Dis. Protect., 116 (4), 182-188.

Ferreras, L., Gomez, E., Toresani, S., Firpo, I., Rotondo, R. (2006). Effect of organic amendments on some physical, chemical and biological properties in a horticultural soil. Bioresour. Technol., 97 (4), 635-640.

Finnan, J., Styles, D. (2013). Hemp: a more sustainable annual energy crop for climate and energy policy. Energy Policy, 58, 152-162.

Grantina-Ievina, L., Andersone, U., Berkolde-Pīre, D., Nikolajeva, V., Ievinsh, G. (2013). Critical tests for determination of microbiological quality and biological activity in commercial vermicompost samples of different origin. Appl. Microbiol. Biotechnol., 97 (24), 10541-10554.

Grantina-Ievina, L., Nikolajeva, V., Rostoks, N., Skrabule, I., Zarina, L., Pogulis, A., Ievinsh, G. (2015). Impact of green manure and vermicompost on soil suppressiveness, soil microbial populations and plant growth in conditions of organic agriculture of Northern temperate climate. In: Meghvansi M. K., Varma A. (eds.). Organic Amendments and Soil 
Suppressiveness in Plant Disease Management. Springer International Publishing, Switzerland, pp. 381-399.

Hartz, T. K., Bottoms, T. G. (2010). Humic substances generally ineffective in improving vegetable crop nutrient uptake or productivity. HortScience, 45 (6), 906-910.

Ievinsh, G. (2011). Vermicompost treatment differentially affects seed germination, seedling growth and physiological status of vegetable crop species. Plant Growth Regul., 65 (1), 169-181.

Karlsons, A., Osvalde, A., Andersone-Ozola, U., Ievinsh, G. (2016). Vermicompost from municipal sewage sludge affects growth and mineral nutrition of winter rye (Secale cereale) plants. J. Plant Nutr., 39 (6), $765-780$

Karlsons, A., Osvalde, A., Necajeva, J., Ievinsh, G. (2008). Changes of nutritional status of coastal plants Hydrocotyle vulgaris and Aster tripolium at elevated soil salinity. Acta Universitatis Latviensis, 745, 165-177.

Lazcano, C., Gómez-Brandón, M., Domínguez, J. (2008). Comparison of the effectiveness of composting and vermicomposting for the biological stabilization of cattle manure. Chemosphere, 72 (7), 1013-1019.

Malceva, M., Vikmane, M., Stramkale, V. (2011). Changes of photosynthesis-related parameters and productivity of Cannabis sativa under different nitrogen supply. Environ. Exp. Biol., 9 (1-2), 61-69.

McWilliam, J. R., Clements, R. J., Dowling, P. M. (1970). Some factors influencing the germination and early seedling development of pasture plants. Austr. J. Agric. Res., 21 (1), 19-32.

Muscolo, A., Bovalo, F., Gionfriddo, F., Nardi, S. (1999). Earthworm humic matter produces auxin-like effects on Daucus carota cell growth and nitrate metabolism. Soil Biol. Biochem., 31 (9), 1303-1311.

Nikbakht, A., Kafi, M., Babalar, M., Xia, Y. P., Luo, A., Etemadi, N.-A. (2008). Effect of humic acid on plant growth, nutrient uptake, and postharvest life of gerbera. J. Plant Nutr., 31 (12), 2155-2167.

Pant, A. P., Radovich, T. J. K., Hue, N. V., Talcott, S. T., Krenek, K. A. (2009). Vermicompost extracts influence growth, mineral nutrients, phytonutrients and antioxidant activity in pak choi (Brassica rapa cv. Bonsai, Chinensis group) grown under vermicompost and chemical fertiliser. $J$. Sci. Food Agric., 89 (14), 2383-2392.

Received 2 November 2016

Accepted in the final form 19 December 2016
Pattnaik, S., Reddy, M. V. (2010). Nutrient status of vermicompost of urban green waste processed by three earthworm species - Eisenia fetida, Eudrilus eugeniae, and Perionyx excavatus. Appl. Environ. Soil Sci., Article ID 967526, doi: 10.1155/2010/967526

Pedra, F., Plaza, C., Fernịndez, J. M., García-Gil, J. C., Polo, A. (2008). Effects of municipal solid waste compost and sewage sludge on chemical and spectroscopic properties of humic acids from a sandy Haplic Podzol and a clay loam Calcic Vertisol in Portugal. Waste Manage., 28 (11), 2183-2191.

Ranalli, P., Venturi, G. (2004). Hemp as a raw material for industrial applications. Euphytica, 140 (1), 1-6.

Sausserde, R., Adamovics, A. (2013). Industrial hemp for biomass production. J. Agric. Eng., 44 (2), e123.

Šimon, T., Czakó, A. (2014). Influence of long-term application of organic and inorganic fertilizers on soil properties. Plant Soil Environ., 60 (7), 314-319.

Tomati, U., Grappelli, A., Galli, E. (1988). The hormone-like effect of earthworm casts on plant growth. Biol. Fertil. Soils, 5 (4), 288-289.

Trevisan, S., Botton, A., Vaccaro, S., Vezzaro, A., Quaggiotti, S., Nardi, S. (2011). Humic substances affect Arabidopsis physiology by altering the expression of genes involved in primary metabolism, growth and development. Environ. Exp. Bot., 74, 45-55.

van der Werf, H. (1994). Crop physiology of fibre hemp (Cannabis sativa L.). Doctoral thesis. Wageningen Agricultural University, Wageningen, Netherlands. $152 \mathrm{pp}$.

Xiaozhai, L., Clarke, R.C. (1995). The cultivation and use of hemp (Cannabis sativa L.) in ancient China. J. Int. Hemp Assoc. 2, 26-33.

Xu, D.-B., Wang, Q.-J., Wu, Y.-C., Yu, G.-H., Shen, Q.-R., Huang, Q.-W (2012). Humic-like substances from different compost extracts could significantly promote cucumber growth. Pedosphere, 22 (6), 815-824.

Yang, C. M., Wang, M. C., Lu, Y. F., Cheng, I. F., Chou, C. H. (2004) Humic substances affect the activity of chlorophyllase. J. Chem. Ecol., 30 (5), 1057-1065.

Zaller, J. G. (2006). Foliar spraying of vermicompost extracts: Effects on fruit quality and indications of late-blight suppression of field-grown tomatoes. Biol. Agric. Hortic., 24 (2), 165-180.

\section{VERMIKOMPOSTA EKSTRAKTA UN NO VERMIKOMPOSTA IZOLĒTU HUMĪNSKĀBJU IETEKME UZ KAṆEPJU SĒKLU DİGŠANU UN DĪGSTU AUGŠANU}

Sējas kaṇepes (Cannabis sativa L.) škiines, ko audzē rūpnieciskai izmantošanai, pēdējā laikā arvien biežāk tiek izmantotas kā ilgtspējīgs alternatīvais materiāls tehnoloǵisko škiedru un bioenerğijas ieguvei un arī kā ḷoti vērtīgs pārtikas un dzīvnieku barības resurss. Pētījuma mērķis bija izvērtēt vermikomposta ekstrakta, vermikomposta minerālvielu un no vermikomposta iegūtas humīnskābes un fulvīnskābes ietekmi uz kaṇepju sēklu dīgšanu un dīgstu augšanu. Kopumā visu vermikomposta sastāvdaḷu atsevišḳa izmantošana apstrādei veicināja gan sēklu dīgšanu, gan hipokotila un dīgḷaknes augšanu, kā arī palielināja hlorofila koncentrāciju dīgḷlapās. Darbīgo koncentrāciju diapazons un veicināšanas pakāpe būtiski atškịiās starp izmantotajiem produktiem. Vermikomposta un no tā iegūtu ekstraktu praktiskā izmantošana varētu būt izmantojama kaṇepju augšanas veicināšanai, lietojot vermikomposta ekstraktu $5 \%$, humīnvielas $0,05 \mathrm{mg} \cdot \mathrm{mL}^{-1}$ un fulvīnskābes $1 \%$ koncentrācijā. 